\title{
Boron Removal from Mining and Synthetic Effluents by Electrocoagulation Using Aluminum Electrodes
}

\author{
Douglas Mark Lopes da Silva, Maria Tereza W. D. Carneiro, and Josimar Ribeiro \\ Departamento de Química, Universidade Federal do Espírito Santo, 29075-910 Vitória, ES, Brazil \\ Correspondence should be addressed to Josimar Ribeiro; josimar.ribeiro@ufes.br
}

Received 30 January 2019; Revised 5 April 2019; Accepted 18 April 2019; Published 9 May 2019

Academic Editor: Cesar Mateo

Copyright (c) 2019 Douglas Mark Lopes da Silva et al. This is an open access article distributed under the Creative Commons Attribution License, which permits unrestricted use, distribution, and reproduction in any medium, provided the original work is properly cited.

\begin{abstract}
The efficiency of the electrocoagulation method to remove boron from synthetic and mining effluents was investigated in this study. Different parameters were tested using boric acid solution and effluent collected from a mining company located in the city of Vitória-ES. The results showed a percentage of boron removal of over $60 \%$ for the synthetic and mining effluents, using aluminum electrodes, $\mathrm{pH} 7.5$, current density of $14.82 \mathrm{~mA} \mathrm{~cm}^{-2}$, and supporting electrolyte of $0.200 \mathrm{~mol} \mathrm{~L}^{-1}$. The electrocoagulation and chemical coagulation methods were also compared, in which the percentage obtained by electrocoagulation was $56.30 \%$ higher for the mining effluent. Thus, electrocoagulation was more efficient in boron removal, especially when appropriate parameters are applied.
\end{abstract}

\section{Introduction}

Boron is an important micronutrient for plants and is found in nature in the form of boric acid and borate salts. This shows a wide application, such as in the manufacture of borosilicate glasses, detergents, cosmetics, and fertilizers. [1] However, boron in high concentration shows toxic effects to the human organism, for example, damage to the reproductive and nervous systems. Thus, the World Health Organization (WHO) sets maximum limits of boron of $0.3 \mathrm{mg} \mathrm{L}^{-1}$ for drinking water [2]. The National Environmental Council (Conselho Nacional de Meio Ambiente, CONAMA) sets a limit of $0.5 \mathrm{mg} \mathrm{L}^{-1}$ for drinking water and a limit of $5.0 \mathrm{mg} \mathrm{L}^{-1}$ to effluents. [3]

Therefore, it is necessary to treat effluents containing boron so that it does not cause damage to the environment. There are several methods to remove boron from a system, among them the electrocoagulation (EC) method. EC is an electrochemical method of waste treatment patented in 1909 in the United States [4], in which a potential difference is applied to metal electrodes immersed in an electrolytic solution, which, under the action of an electric current, produces coagulant species in situ. Thus, the coagulating agent is formed by oxidation of the electrode which, simultaneously, also form hydroxyl ions and gases. The oxidized metal together with the hydroxyl ions form metallic hydroxides that will act as coagulants in the system. [4,5]

The produced coagulant increases the ionic strength of the system, neutralizing the surface charges of the contaminating particles, destabilizing them and, consequently, allowing them to approach and start the flocculation process. This process consists in the agglomeration of the neutralized colloidal particles, in which there is an increase in the size of the flocs due to van der Waals forces between them, resulting in a sedimentation process. After that, sedimentation of the contaminating particles can be removed from the system by filtration $[5,6]$. During EC, gases are also formed, and they are adsorbed on the surface of the contaminating particle, assisting in the removal process by flotation, in which the particles remain on the surface of the system $[4,7]$.

In EC, many metals can be used, but the most used are aluminum and iron due to high efficiency and low cost. EC reactions using aluminum electrodes are demonstrated by the following equations and the standard reduction potential (versus SHE, standard hydrogen electrode) at $298 \mathrm{~K}$ and $1 \mathrm{~atm}$ [1]. 
Anode:

$$
\begin{aligned}
& 2 \mathrm{Al}_{(\mathrm{S})} \leftrightharpoons 2 \mathrm{Al}_{(\mathrm{aq})}^{3+}+6 \mathrm{e}^{-} \quad \mathrm{E}^{\circ}=+1.662 \mathrm{~V} \\
& 3 \mathrm{H}_{2} \mathrm{O}_{(\mathrm{l})} \leftrightharpoons \frac{3}{2} \mathrm{O}_{2(\mathrm{~g})}+6 \mathrm{H}_{(\mathrm{aq})}^{+}+6 \mathrm{e}^{-} \\
& \mathrm{E}^{\circ}=-1.229 \mathrm{~V}
\end{aligned}
$$

Cathode:

$$
\begin{aligned}
& 12 \mathrm{H}_{2} \mathrm{O}_{(\mathrm{l})}+12 \mathrm{e}^{-} \leftrightharpoons 6 \mathrm{H}_{2(\mathrm{~g})}+12 \mathrm{OH}_{(\mathrm{aq})}^{-} \\
& \mathrm{E}^{\circ}=-0.828 \mathrm{~V}
\end{aligned}
$$

Global:

$$
\begin{aligned}
2 \mathrm{Al}_{(\mathrm{S})}+9 \mathrm{H}_{2} \mathrm{O}_{(\mathrm{l})} \leftrightharpoons & 2 \mathrm{Al}(\mathrm{OH})_{3(\mathrm{aq})}+\frac{3}{2} \mathrm{O}_{2(\mathrm{~g})} \\
& +6 \mathrm{H}_{2(\mathrm{~g})}
\end{aligned}
$$

Another species may arise from the hydrolysis reaction of the ion $\mathrm{Al}^{3+}$ during the EC process as the $\mathrm{pH}$ of the system increases, for example, $\mathrm{Al}(\mathrm{OH})^{2+}, \mathrm{Al}(\mathrm{OH})_{2}{ }^{+}$, and $\mathrm{Al}(\mathrm{OH})_{4}{ }^{-}$. The $\mathrm{Al}(\mathrm{OH})_{4}{ }^{-}$, known as tetrahydroxoaluminate, is an anion predominant at $\mathrm{pH}$ greater than 10.0 and water-soluble. The formation of this anion in the system impairs the flocculation process; thus, it is necessary to control the $\mathrm{pH}$ of the system during $\mathrm{EC}$ [2]. In addition to $\mathrm{pH}$ control, other parameters may also contribute to process optimization, such as current density, supporting electrolyte concentration, and EC time $[4,8]$. Thus, Kartikaningsh et al. (2016) [1], using boron concentration of $100 \mathrm{mg} \mathrm{L}^{-1}$, current density of $2.5 \mathrm{~mA} \mathrm{~cm}^{-2}$, $\mathrm{pH} 8.0$, and $\mathrm{NaCl}$ as supporting electrolyte, obtained about $90 \%$ of boron removal. Similarly, Sari and Chellam (2015) [9] obtained approximately $60 \%$ of boron removal when using a system with a current density of $50 \mathrm{mAcm}-2$ and $\mathrm{pH}$ 8.0. Thus, EC has the advantages of low secondary waste production, low operating costs, formation of larger and more stable flakes, and the production of gases that aid the removal of waste by flotation. [5] In this way, this research article aimed to remove boron in a synthetic effluent and in a mining effluent by EC method using aluminum electrodes, as well as the analysis of the method against $\mathrm{pH}$ variation, concentration of the supporting electrolyte, current density, and EC time. In this research, the efficiency of the EC method was also compared with the chemical coagulation method (CQ) using aluminum sulfate as coagulant.

\section{Experiment}

2.1. Electrocoagulation Cell. The cell used for EC was made of acrylic with $8 \mathrm{~mm}$ of thickness and sizes from $17.1 \mathrm{~cm} \mathrm{x} 17.1 \mathrm{~cm}$ $\mathrm{x} 17.1 \mathrm{~cm}$, with a total volume of $5 \mathrm{~L}$, with gas outlet valves and electrodes projected on the cap by screw connection. As power source, a DC Power Supply INSTRUTHERM FA3003 was used, with potential from 0 to $30 \mathrm{~V}$ and current from 0 to $3.0 \mathrm{~A}$. The electrodes were prepared in aluminum alloy 1100 (Metalthaga), with an aluminum percentage of $99 \%$. The dimensions of the plates immersed in solution were $10 \mathrm{~cm} \mathrm{x}$
TABLE 1: Characteristics of the effluent collected in the STS (Sawage Treatment Station) of the mining company.

\begin{tabular}{lc}
\hline Composition & Concetration $\left(\mathrm{mg} \mathrm{L}^{-1}\right)$ \\
\hline Boron & 16.22 \\
Total carbon & 181.0 \\
Phenols index & 0.053 \\
Phosphor & 72.50 \\
Total nitrate & 0.700 \\
Total nitrite & 0.309 \\
Ammoniacal nitrogen & 7.100 \\
Total nitrogen & 14.00 \\
Surfactants & 0.128 \\
Total suspended solids & 150.0 \\
Total fixed solids & 55.00 \\
Volatile suspended solids & 95.00 \\
Total oils and greases & 146.0 \\
BOD $*$ & 262.0 \\
COD $* *$ & 1910.0 \\
\hline
\end{tabular}

* Biochemical oxygen demand; ** COD: chemical oxygen demand

$10 \mathrm{~cm} \times 0.2 \mathrm{~cm}$, thus presenting a surface area of $208 \mathrm{~cm}^{-2}$ and a pair of electrodes in the reactor. At start of each experiment the electrodes were sanded with silicon carbide sandpaper of 220 and 600 grades $(3 \mathrm{M})$.

2.2. Electrocoagulation of the Synthetic and Mining Effluents. The synthetic effluent was prepared from boric acid (99\%, Neon) and sodium nitrate (99\%, Dinâmica) was used as supporting electrolyte. To reach $4 \mathrm{~L}$ of volume, it was completed with deionized water from the water purifier Sartorius Arium ${ }^{\circledR}$, obtaining a $200 \mathrm{mg} \mathrm{L}^{-1}$ boron solution and supporting electrolyte with concentrations of $0.100 \mathrm{~mol} \mathrm{~L}^{-1}$, $0.200 \mathrm{~mol} \mathrm{~L}^{-1}$, and $0.400 \mathrm{~mol} \mathrm{~L}^{-1}$. On the other hand, the mining effluent was collected in the treatment plant of a mining company of the city of Vitória and the characteristics of the effluent of the mining company are presented in Table 1.

The EC of the synthetic effluent was carried out varying some parameters, such as current density in $4.81 \mathrm{~mA} \mathrm{~cm}^{-2}$ and $14.42 \mathrm{~mA} \mathrm{~cm}^{-2}$, electrolysis duration of $30,60,90$, and 120 minutes, supporting electrolyte concentration and $\mathrm{pH}$ control in the range of 7.5 and 13.0. The samples with $\mathrm{pH}$ control were made in 120 minutes and electrolyte with concentration of $0.200 \mathrm{~mol} \mathrm{~L}^{-1}$, adding $\mathrm{HCl} 1.000 \mathrm{~mol} \mathrm{~L}^{-1}$ for adjustment of the $\mathrm{pH}$. After obtaining the boron removal results and the operational cost for the synthetic effluent, the best parameters were chosen for the mining effluent. Thus, for the mining effluent, a duration of 90 minutes was used, applying current density of $14.42 \mathrm{~mA} \mathrm{~cm}^{-2}$ and using potassium chloride solution (99\%, Dinâmica) at the concentration of $0.400 \mathrm{~mol} \mathrm{~L}^{-1}$ as supporting electrolyte.

2.3. Jar Test. To compare the EC and CQ results, jar tests were performed. This test consisted of CQ with the addition of hydrated aluminum sulfate (98\%, Dinâmica) as a coagulating agent. The tests were performed in a Jar Test 
TABLE 2: EC data to estimate the operational cost of synthetic effluent for 30, 60, 90, and 120 minutes using a current (i) of 3.0 A and supporting electrolyte (ES) of $0.200 \mathrm{~mol} \mathrm{~L}^{-1}$, and for the mining effluent, for 90 minutes, using $3.0 \mathrm{~A}$ of current and $0.400 \mathrm{~mol} \mathrm{~L}^{-1}$ of supporting electrolyte.

\begin{tabular}{lccccccc}
\hline Effluent & Time $(\mathrm{min})$ & Potential $(\mathrm{V})$ & $\mathrm{i}(\mathrm{A})$ & Vol. $(\mathrm{L})$ & $\mathrm{ES}(\mathrm{g})$ & $\left.\mathrm{CE}_{(\mathrm{Wh} \mathrm{L}}^{-1}\right)$ & $\left.\mathrm{ME}^{\mathrm{g}}\right)$ \\
\hline Synthetic & 30 & 12.6 & 3.0 & 4.0 & 68.00 & 4.725 \\
Synthetic & 60 & 12.5 & 3.0 & 4.0 & 68.00 & 9.375 \\
Synthetic & 90 & 11.7 & 3.0 & 4.0 & 68.00 & 13.162 \\
Synthetic & 120 & 12.8 & 3.0 & 4.0 & 68.00 & 1.006 \\
Mining & 90 & 3.5 & 3.0 & 4.0 & 29.80 & 1.510 \\
\hline
\end{tabular}

(Ethik Technology@), model 218-6LDB, using the coagulant mass corresponding to that produced in the EC, previously calculated by Faraday's equation (5).

$$
m=i . t . \frac{M}{n F}
$$

In which $i$ is the current $(A)$, $\mathrm{t}$ is time $(s), \mathrm{M}$ is the molar mass $\left(\mathrm{g} \mathrm{mol}^{-1}\right), \mathrm{n}$ is the quantity of electrons $(\mathrm{mol})$, and $\mathrm{F}$ is the Faraday's constant with a value of $96485 \mathrm{C} \mathrm{mol}^{-1}$ [10].

The coagulation times for the synthetic effluent were 30 minutes and 60 minutes. The 30-minute experiment was divided into 5 minutes at $150 \mathrm{rpm}, 10$ minutes at $20 \mathrm{rpm}$, and 15 minutes at rest; and the 60-minute one was divided into 5 minutes at $150 \mathrm{rpm}, 25$ minutes at $20 \mathrm{rpm}$, and 30 minutes at rest. For the mining effluent, the duration used was 90 minutes, divided into 5 minutes at $150 \mathrm{rpm}, 25$ minutes at $20 \mathrm{rpm}$, and 60 minutes at rest. The $\mathrm{pH}$ of the system was corrected to 8.0 using a sodium hydroxide solution of $1.000 \mathrm{~mol} \mathrm{~L}^{-1}$.

All samples produced by EC and CQ were analyzed by ICP-MS (Inductively Coupled Plasma Mass Spectrometry), in which a Nexlon 300D Perkin Elmer equipment was used, with a radiofrequency power of $1500.00 \mathrm{~W}$, nebulization gas flow of $0.98 \mathrm{~L} \mathrm{~min}^{-1}$, auxiliary gas $1.200 \mathrm{Lmin}^{-1}$, and plasma gas $16.00 \mathrm{~L} \mathrm{~min}^{-1}$, with sample aspiration rate of $0.500 \mathrm{~mL} \mathrm{~min}^{-1}$.

2.4. Operational Cost. The energy consumption (CE) of the electrolytic cell and the operational cost (CO) for the EC were estimated by (6) and (7) [11].

$$
\begin{aligned}
C E & =i \cdot U \cdot \frac{t}{v} \\
C O & =a C E+b M E+c E S
\end{aligned}
$$

In which $i$ is the current $(A), \mathrm{U}$ is the voltage $(V), \mathrm{t}$ is time (minutes), and $\mathrm{V}$ is the volume of the solution $(L)$ [10]. For the operational cost, $\mathrm{ME}$ is the consumed mass of electrodes $(g)$, ES is the mass of the supporting electrolyte $(g)$, and coefficients $\mathrm{a}, \mathrm{b}$, and $\mathrm{c}$ are the cost (US\$) of energy, aluminum, and supporting electrolyte, respectively [11]. The experimental data are shown in Table 2.

In order to calculate the energy cost, data from the EDP Espírito Santo Distribuição de Energia S.A were used, in which the cost per $\mathrm{kWh}$ was US\$ $0.127 / \mathrm{kWh}$. For sodium nitrate, aluminum mass, and potassium chloride, the cost was US\$ $4.14 / \mathrm{kg}$, US\$ $8.05 / \mathrm{kg}$, and US\$ $7.81 / \mathrm{kg}$, respectively. To

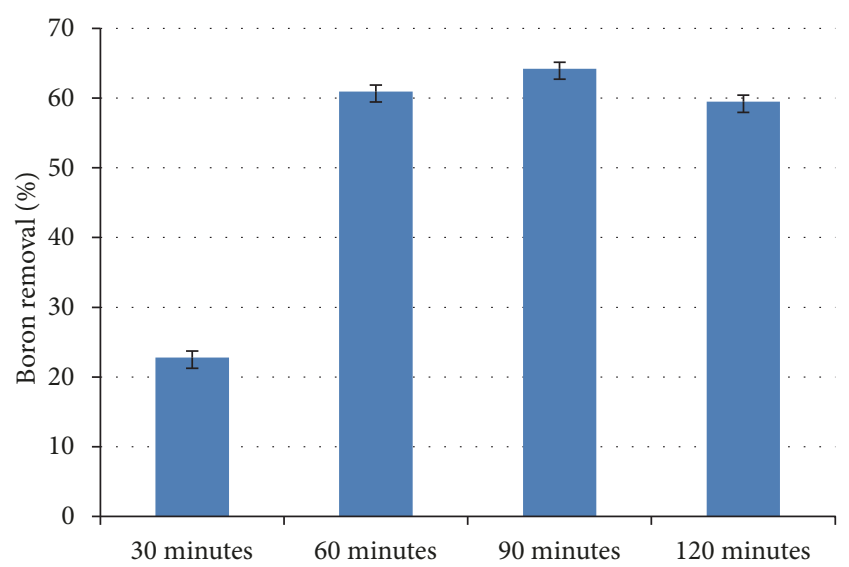

FIGURE 1: Percentage of boron removal as a function of EC time, using current density of $14.42 \mathrm{~mA} \mathrm{~cm}^{-2}$ and supporting electrolyte at the concentration of $0.200 \mathrm{~mol} \mathrm{~L}^{-1}$.

calculate the operational cost of CQ, the respective masses of $6.210 \mathrm{~g}, 12.330 \mathrm{~g}$, and $18.618 \mathrm{~g}$ of aluminum sulfate were used for the durations of 30,60, and 90 minutes, respectively, and the cost was US\$20.49/kg. The mass of sodium hydroxide used for $\mathrm{pH}$ correction was $3.6 \mathrm{~g}$ per jar, with a cost of US\$ $24.39 / \mathrm{kg}$.

\section{Results and Discussion}

Table 3 shows the results obtained by ICP-MS of EC and $\mathrm{CQ}$ for the synthetic and mining effluents regarding different parameters such as $\mathrm{pH}$, supporting electrolyte concentration, current density, and EC time.

3.1. Boron Removal as a Function of Electrocoagulation Time in the Synthetic Effluent. An increase in boron removal was observed when EC time was increased (30, 60, and 90 minutes) using a current density of $14.42 \mathrm{~mA} \mathrm{~cm}^{-2}$ and supporting electrolyte at a concentration of $0.200 \mathrm{~mol} \mathrm{~L}^{-1}$ (Table 3). In the 120-minute test, boron removal was reduced. Such data are shown in Figure 1.

According to Faraday's equation (5), electrolysis time is directly proportional to the produced mass of coagulant [10]. Thus, with increasing electrolysis duration, the amount of ions $\mathrm{Al}^{3+}$ and $\mathrm{OH}^{-}$formed from electrode oxidation increases. These species in aqueous media form aluminum hydroxide which acts as a coagulant in the system [11, 12]. However, with the increase in the formation of aluminum 
TABLE 3: Results obtained for the electrocoagulation and chemical coagulation tests for a synthetic effluent with initial boron concentration of $200 \mathrm{mg} \mathrm{L}^{-1}$ and for the effluent of mining company with initial boron concentration of $16.220 \mathrm{mg} \mathrm{L}^{-1}$.

\begin{tabular}{|c|c|c|c|c|c|c|c|}
\hline Effluent & Test & {$[\mathrm{ES}] \mathrm{mol} \mathrm{L}^{-1}$} & $\mathrm{pH}$ & $\mathrm{j}\left(\mathrm{mA} \mathrm{cm}^{-2}\right)$ & Time $(\min )$ & {$[\mathrm{B}] \mathrm{mgL}^{-1}$} & Boron removal (\%) \\
\hline Synthetic & $\mathrm{EC}$ & 0.400 & 8.4 & 14.42 & 30 & 149.57 & 25.2 \\
\hline Synthetic & EC & 0.100 & 8.7 & 14.42 & 30 & 170.03 & 15.0 \\
\hline Synthetic & $\mathrm{EC}$ & 0.200 & 7.8 & 4.81 & 30 & 165.96 & 17.0 \\
\hline Synthetic & EC & 0.200 & 8.5 & 14.42 & 30 & 154.42 & 22.8 \\
\hline Synthetic & CQ & - & 8.0 & - & 60 & 151.71 & 24.1 \\
\hline Synthetic & CQ & - & 8.0 & - & 30 & 164.86 & 17.6 \\
\hline Synthetic & $\mathrm{EC}$ & 0.200 & 10.7 & 14.42 & 60 & 78.07 & 60.9 \\
\hline Synthetic & $\mathrm{EC}$ & 0.200 & 11.9 & 14.42 & 90 & 71.52 & 64.2 \\
\hline Synthetic & $\mathrm{EC}$ & 0.200 & 13.1 & 14.42 & 120 & 81.00 & 59.5 \\
\hline Synthetic & $\mathrm{ECpH}$ & 0.200 & 7.5 & 14.42 & 120 & 69.80 & 65.1 \\
\hline Mining & EC & 0.400 & 7.5 & 14.42 & 90 & 4.93 & 69.5 \\
\hline Mining & $\mathrm{EC}$ & 1.000 & 7.5 & 14.42 & 90 & 4.58 & 71.6 \\
\hline Mining & CQ & - & 8.0 & - & 90 & 14.54 & 13.9 \\
\hline
\end{tabular}

$\mathrm{ECpH}=$ electrocoagulation with $\mathrm{pH}$ control at $7.5 ; \mathrm{j}=$ current density; $[\mathrm{ES}]=$ supporting electrolyte concentration; $\mathrm{EC}=$ electrocoagulation; $\mathrm{CQ}=$ chemical coagulation

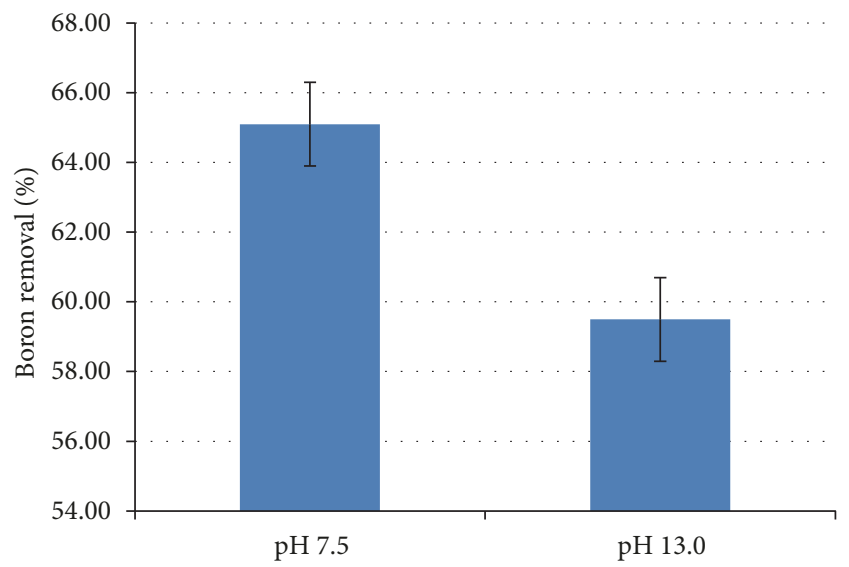

Figure 2: Percentage of boron removal by EC using current density of $14.42 \mathrm{~mA} \mathrm{~cm}^{-2}$, supporting electrolyte $0.200 \mathrm{~mol} \mathrm{~L}^{-1}$ and duration of 120 minutes for two $\mathrm{pH}$ (7.5 and 13.0), in which $\mathrm{pH}$ control was performed with addition of $\mathrm{HCl} 1.000 \mathrm{~mol} \mathrm{~L}^{-1}$.

hydroxide, the $\mathrm{pH}$ of the system also increases. At high $\mathrm{pH}(\mathrm{pH}>10)$ the coagulant species are negatively charged to $\mathrm{Al}(\mathrm{OH})_{4}{ }^{-}$. This species is soluble, which decreases the formation of flakes formed and, consequently, decreases the removal of boron. In this way, in the duration of 120 minutes, ion $\mathrm{Al}(\mathrm{OH})_{4}{ }^{-}$was formed due to the increased $\mathrm{pH}$, reducing the percentage of removal of boron. $[10,13,14]$ Thus, it was necessary to control the $\mathrm{pH}$ by adding $\mathrm{HCl} 1.000 \mathrm{~mol} \mathrm{~L}^{-1}$. The results obtained can be observed in Figure 2 for the $\mathrm{pH}$ of 7.5 and 13.0.

In Figure 2, an increase is observed in the percentage of boron removal at $\mathrm{pH}=7.50$ when compared to $\mathrm{pH}=13.0$, because, in this $\mathrm{pH}$, there is no formation of the water-soluble species $\mathrm{Al}(\mathrm{OH})_{4}{ }^{-}$.

3.2. Boron Removal as a Function of the Supporting Electrolyte Concentration in the Synthetic Effluent. The supporting electrolyte, when added at high concentrations, can give the

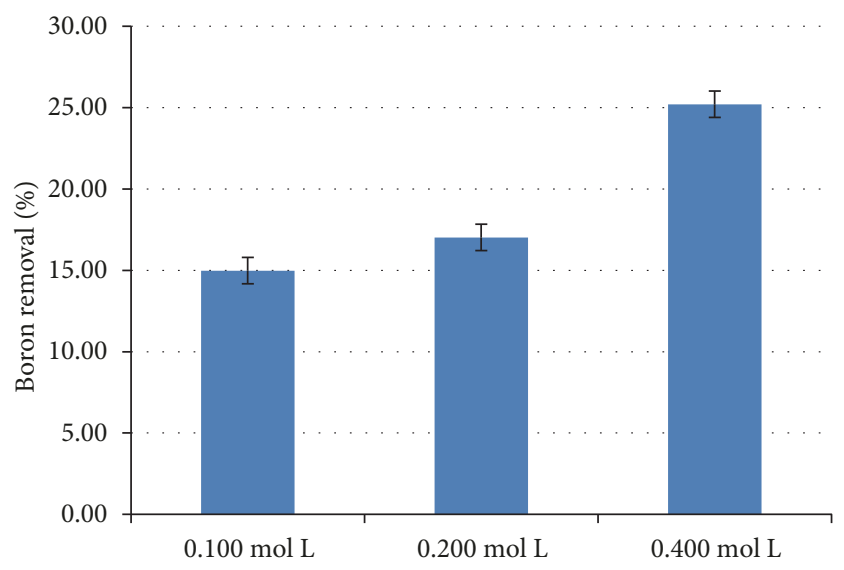

FIgURE 3: Percentage of boron removal versus variation in supporting electrolyte concentration at $0.100,0.200$, and $0.400 \mathrm{~mol} \mathrm{~L}^{-1}$, applying current density of $14.42 \mathrm{~mA} \mathrm{~cm}^{-2}$ and EC time of 30 minutes.

solution and interface metal-solution properties, which, in general, results in the maintenance of the high and constant ionic strength of the solution. The supporting electrolyte shows its optimized efficiency when the concentration is 100 times greater than the concentration of the electroactive species of the solution [13-15]. Figure 3 shows an increase in the percentage of boron removal with the increased supporting electrolyte used.

Thus, the increase in electrolyte concentration of 0.100 to $0.400 \mathrm{~mol} \mathrm{~L}^{-1}$ decreased the resistance of the solution, increasing the percentage of boron removal in the system and reducing energy cost, as shown by the result.

3.3. Boron Removal as a Function of Current Density in the Synthetic Effluent. As already shown by (5), the applied current is directly proportional to the mass of ions $\mathrm{Al}^{3+}$ produced in the system. Thus, the increase in applied current density increases the production of coagulating agent in 


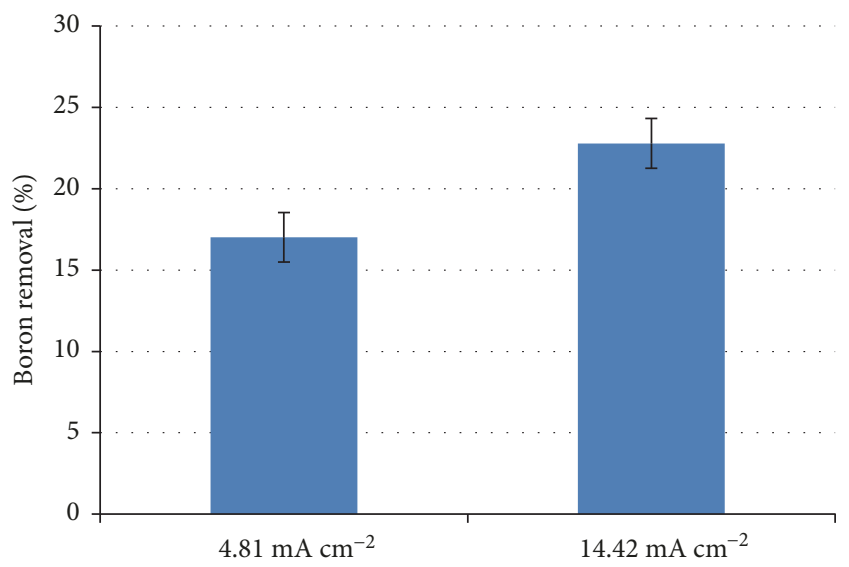

FIgURE 4: Percentage of boron removal at the current densities of 4.81 and $14.42 \mathrm{~mA} \mathrm{~cm}^{-2}$, with an EC time of 30 minutes and supporting electrolyte of $0.200 \mathrm{~mol} \mathrm{~L}^{-1}$.

the system [10]. Such a result can be seen in Figure 4, where increasing the current density from $4.81 \mathrm{~mA} \mathrm{~cm}^{-2}$ to $14.42 \mathrm{~mA} \mathrm{~cm}^{-2}$, for an EC time of 30 minutes, increased boron removal.

Although an increase in the boron removal is observed with increasing current density, when considering the standard deviation, such increase was not as significant. This is due to the increase in the formation of aluminum oxide that accompanies the formation of the coagulant. This is deposited on the surface of the electrode in a process called passivation, in which there is an increase in the resistance of the system and decrease in the efficiency of the method. Thus, despite increasing current density, a significant percentage difference in boron removal was not observed [16]. An alternative to reduce the passivation of electrodes is the addition of soluble anions with aluminum, such as chlorides and nitrates, because such species aid in the solubilization of the formed oxide. Such evidence can be observed in Figure 3, in which the increase in $\mathrm{NaNO}_{3}$ concentration increased boron removal. These results agree with the literature data $[16,17]$.

3.4. Comparison between the Percentage of Boron Removal in the Electrocoagulation and Chemical Coagulation in the Synthetic and the Mining Effluents. When EC was performed at 30 and 60 minutes, with current density of $14.42 \mathrm{~mA} \mathrm{~cm}^{-2}$ and supporting electrolyte $0.200 \mathrm{~mol} \mathrm{~L}^{-1}$ for the synthetic effluent, a higher boron removal was observed for EC when compared to the CQ process using aluminum sulfate as coagulant (Figure 5). It was also possible to observe a significant increase in the percentage of boron removal when time was increased from 30 to 60 minutes.

During the EC process, coagulating agent and gases in situ are formed. The coagulating agent produced is insoluble in water and, when adsorbed on the surface of the contaminant, it forms flocs in a process called flocculation $[5,10]$. The gases produced in situ contribute to boron removal by flotation, in which the gaseous molecules interact with the contaminating particles, which remain suspended in the system $[10,18]$. In $\mathrm{CQ}$, on the other hand, the coagulating agent, in this

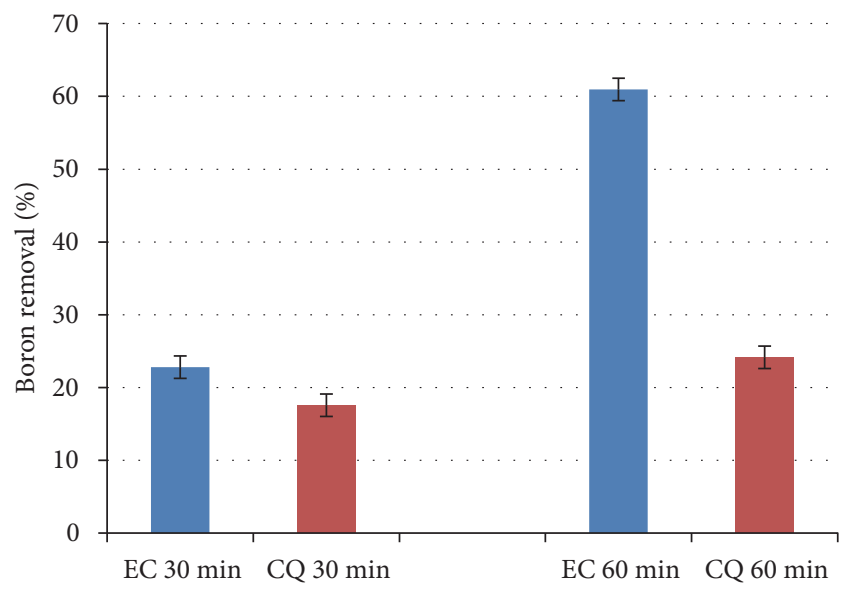

$$
\begin{aligned}
& \text { EC } 30 \mathrm{~min} \\
& \text { CQ } 30 \mathrm{~min} \\
& \text { EC } 60 \mathrm{~min} \\
& \text { CQ } 60 \mathrm{~min}
\end{aligned}
$$

FIGURE 5: Boron removal by EC using supporting electrolyte of $0.200 \mathrm{~mol} \mathrm{~L}^{-1}$ and current density of $14.42 \mathrm{~mA} \mathrm{~cm}^{-2}$ and by CQ using $\mathrm{Al}_{2}\left(\mathrm{SO}_{4}\right)_{3}$, for 30 and 60 minutes.

case aluminum sulfate, is added to the system and, from the hydrolysis of the salt added, aluminum hydroxide is formed, as demonstrated by

$$
\begin{aligned}
\mathrm{Al}_{2}\left(\mathrm{SO}_{4}\right)_{3(\mathrm{aq})} & \leftrightharpoons 2 \mathrm{Al}^{3+}{ }_{(\mathrm{aq})}+3 \mathrm{SO}_{4}{ }_{(\mathrm{aq})}^{2-} \\
2 \mathrm{Al}^{3+}{ }_{(\mathrm{aq})}+6 \mathrm{H}_{2} \mathrm{O}_{(\mathrm{l})} & \leftrightharpoons 2 \mathrm{Al}(\mathrm{OH})_{3(\mathrm{aq})}+6 \mathrm{H}^{+}{ }_{(\mathrm{aq})}
\end{aligned}
$$

The formed ions $\mathrm{H}^{+}$decrease the $\mathrm{pH}$ of the system, making it difficult to form aluminum hydroxide, thus producing less coagulant. Therefore, EC is an advantageous method when compared to $\mathrm{CQ}$, because in addition to the production of the coagulant agent in situ, gases are formed, which act in the removal of boron by flotation, increasing the production of these species along with EC time, as it can be observed in Figure 5. Similar behavior has been also observed by others $[5,10]$.

Thus, in the mining effluent, Figure 6 also shows a higher percentage of boron removal by the EC process compared to the CQ method, using the effluent from a mining company of 90 minutes, current density of $14.42 \mathrm{~mA} \mathrm{~cm}^{-2}$, and supporting electrolyte concentration of $0.400 \mathrm{~mol} \mathrm{~L}^{-1}$ and $1.00 \mathrm{~mol} \mathrm{~L}^{-1}$.

The results shown in Figure 6 and Table 3 indicate that the electrocoagulation at both supporting electrolyte concentrations left the effluent of the mining company within the parameters required by resolution of CONAMA $n^{\circ}$ $396 / 2008$ of $5.00 \mathrm{mg} \mathrm{L}^{-1}$. Thus, the effluent from the mining company after electrocoagulation presents satisfactory boron levels. When one compares the results with the literature, for example, Wided et al. [17], using a current of $86.44 \mathrm{~mA} . \mathrm{cm}^{-2}$, for 60 minutes and with boron concentration of $5 \mathrm{mg} \mathrm{L}^{-1}$, the 
TABLE 4: Energy and operational costs for EC, for the synthetic effluent, performed for 30, 60, 90, and 120 minutes, current density of $14.42 \mathrm{~mA} \mathrm{~cm}^{-2}$ and supporting electrolyte $0.200 \mathrm{~mol} \mathrm{~L}^{-1}$, and for the mining effluent with a current density of $14.42 \mathrm{~mA} \mathrm{~cm}^{-2}$, for $90 \mathrm{minutes}$ and supporting electrolyte $0.400 \mathrm{~mol} \mathrm{~L}^{-1}$.

\begin{tabular}{lccc}
\hline Effluent & Time $(\mathrm{min})$ & Energy cost (US\$) & Operational cost (US\$) \\
\hline Synthetic & 30 & 0.00060 & 0.187 \\
Synthetic & 60 & 0.00120 & 0.191 \\
Synthetic & 90 & 0.00167 & 0.196 \\
Synthetic & 120 & 0.00244 & 0.200 \\
Mining & 90 & 0.00050 & 0.245 \\
\hline
\end{tabular}

TABLE 5: Comparison of operational cost in the electrocoagulation (EC) and chemical coagulation (CQ), during 60 minutes for synthetic effluent and, for mining effluent, 90 minutes, using current density of $14.42 \mathrm{~mA} \mathrm{~cm}^{-2}$ in the EC.

\begin{tabular}{lcccc}
\hline Effluent & EC-cost (US\$) & CQ-cost (US\$) & Boron removal EC (\%) & Boron removal CQ (\%) \\
\hline Synthetic & 0.191 & 0.343 & 60.9 & 24.1 \\
Mining & 0.245 & 0.469 & 69.0 & 12.7 \\
\hline
\end{tabular}

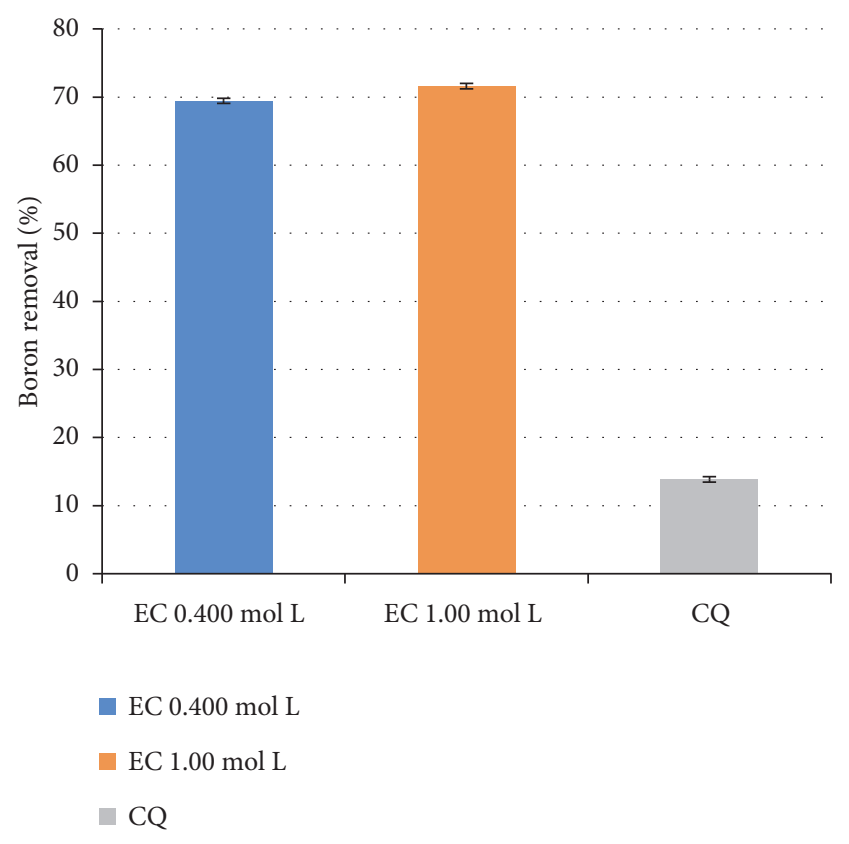

FIgURE 6: Percentage of boron removal from the mining effluent by EC for 90 minutes, current density of $14.42 \mathrm{~mA} \mathrm{~cm}^{-2}$ and supporting electrolyte concentration of $0.400 \mathrm{~mol} \mathrm{~L}^{-1}$ and $1.00 \mathrm{~mol} \mathrm{~L}^{-1}$, and by CQ for 90 minutes using aluminum sulfate as coagulant.

authors obtained a 23\% higher boron removal in EC when compared to CQ. Kartikaningsih et al. [1], using a current of $2.5 \mathrm{~A}, \mathrm{pH}=8.0$, for 180 minutes and boron concentration of $100 \mathrm{mg} \mathrm{L}^{-1}$, obtained a percentage of boron removal $18 \%$ higher for EC when compared to CQ.

3.5. Operational Cost of EC and Comparison with Chemical Coagulation. The operational cost was calculated based on (6) and (7) and with the data listed in Table 2. Thus, Table 4 shows the energy and operational costs of the EC process for the synthetic and mining effluents.
In Table 4, it can be observed that increasing the time from 30 to 60 minutes increases the operational cost; however, as shown in Figure 1, the percentage of boron removal has a significant increase when duration goes from 30 to 60 minutes, which shows a more satisfactory result because the increase in cost was small.

Ezechi et al. [19], treating $1.0 \mathrm{~L}$ of synthetic effluent containing boron at a concentration of $20 \mathrm{mg} \mathrm{L}^{-1}$ during a 60 -minute EC time and a current density of $12.5 \mathrm{~mA} \mathrm{~cm}^{-2}$, obtained an operational cost of US\$ 0.22. According to the author, an operational cost considered satisfactory should be less than US\$1.27. Thus, the results obtained for the synthetic and mining effluents were satisfactory.

Table 5 shows the comparison between the operational cost of EC and CQ, of 60 minutes for the synthetic effluent, and 90 minutes for the mining effluent.

The results demonstrate that EC is an important method for waste treatment, since it was more efficient and advantageous for both effluents. In addition to its lower operational cost, a significant increase in boron removal was also obtained.

\section{Conclusion}

The results showed that the use of EC was an important method for the removal of boron in synthetic effluent and mining effluent in the mining company, where a boron removal of more than $60 \%$ was observed in both effluents, and became the effluent of the mining company have levels of boron below the maximum allowed by CONAMA. A low operational cost was also observed, not exceeding US\$ 0.20 for the synthetic effluent and US\$ 0.303 for the mining effluent. When comparing EC and CQ, the electrochemical method proved to be more advantageous, because in addition to a lower operational cost, a significant increase in the percentage of boron removal was also obtained. The results also showed that the variation of parameters such as $\mathrm{pH}$, current density, supporting electrolyte concentration and EC time may contribute to a higher boron removal, a fact 
observed for the synthetic effluent. Thus, EC is an important technique that can be applied in the removal of industrial waste and can be used to reduce environmental impacts caused by the release of these effluents into rivers and soil, avoiding risks to the environment and human health.

\section{Data Availability}

The data used to support the findings of this study are available from the corresponding author upon request.

\section{Conflicts of Interest}

The authors declare that they have no conflicts of interest.

\section{Acknowledgments}

This study was partially financed by the Coordenação de Aperfeiçoamento de Pessoal de Nível Superior, Brasil (CAPES), by the Fundação de Amparo à Pesquisa e Inovação do Espírito Santo (FAPES/VALE), by the Conselho Nacional de Desenvolvimento Científico e Tecnológico (CNPq), and by the Universidade Federal do Espírito Santo (UFES).

\section{References}

[1] D. Kartikaningsih, Y.-J. Shih, and Y.-H. Huang, "Boron removal from boric acid wastewater by electrocoagulation using aluminum as sacrificial anode," Sustainable Environment Research, vol. 26, no. 4, pp. 150-155, 2016.

[2] A. A. Halim, A. F. A. Bakar, M. A. K. M. Hanafiah, and H. Zakaria, "Boron removal from aqueous solutions using curcumin-aided electrocoagulation," Middle East Journal of Scientific Research, vol. 11, no. 5, pp. 583-588, 2012.

[3] Brasil, "Condições padrões de qualidade da água, Conselho Nacional do Meio Ambiente," CONAMA, Resolução No 396/08, Brasília, 2008, http://www2.mma.gov.br/port/conama/ legiabre.cfm? codlegi $=562$.

[4] H. A. Moreno, D. L. Cocke, J. A. Gomes et al., "Electrochemistry behind electrocoagulation using iron electrodes," ECS Transactions, vol. 6, no. 9, pp. 1-15, 2007.

[5] M. M. Emamjomeh, Electrocoagulation technology as a process for defluoridation in water treatment [Ph.D Thesis], University of Wollongong, Wollongong, Australia, 2006.

[6] E. Butler, Y. Hung, R. Y. Yeh, and M. Suleiman Al Ahmad, "Electrocoagulation in Wastewater Treatment," Water, vol. 3, no. 2, pp. 495-525, 2011.

[7] K. J. Howe, D. W. Hand, J. C. Crittenden, R. R. Trussell, and G. Tchobanoglous, Principles of Water Treatment, John Wiley and Sons, Inc, New Jersey, NJ, USA, 3rd edition, 2012.

[8] N. Bektaş, S. Öncel, H. Y. Akbulut, and A. Dimoglo, "Removal of boron by electrocoagulation," Environmental Chemistry Letters, vol. 2, pp. 52-54, 2004.

[9] M. A. Sari and S. Chellam, "Mechanisms of boron removal from hydraulic fracturing wastewater by aluminum electrocoagulation," Journal of Colloid and Interface Science, vol. 458, pp. 103111, 2015.

[10] D. Kartikaningsih and Y. H. Huang, "Comparison of chemical coagulation and electrocoagulation for boron removal from synthetic wastewater using aluminium," International Journal of Chemical and Molecular Engineering, vol. 9, pp. 945-947, 2015.

[11] V. Kuokkanen, Utilization of Electrocoagulation for Water and Wastewater Treatment and Nutrient Recovery [Ph.D. thesis], University of Oulu, Oulu, Finland, 2016.

[12] A. E. Yilmaz, R. Boncukcuoğlu, and M. M. Kocakerim, "A quantitative comparison between electrocoagulation and chemical coagulation for boron removal from boron-containing solution," Journal of Hazardous Materials, vol. 149, no. 2, pp. 475481, 2007.

[13] B. Z. Can, R. Boncukcuoğlu, A. E. Yılmaz, and B. A. Fil, "Arsenic and boron removal by electrocoagulation with aluminum electrodes," Arabian Journal for Science and Engineering, vol. 41, no. 6, pp. 2229-2237, 2016.

[14] A. M. O. Brett and C. M. A. Brett, Electrochemistry: Principles, Methods, and Applications, Oxford University Press, Oxford, UK, 1994.

[15] A. E. Yilmaz, R. Boncukcuoǧlu, M. M. Kocakerim, and B. Keskinler, "The investigation of parameters affecting boron removal by electrocoagulation method," Journal of Hazardous Materials, vol. 125, no. 1-3, pp. 160-165, 2005.

[16] K. Missaoui, W. Bouguerra, C. Hannachi, and B. Hamrouni, "Boron removal by electrocoagulation using full factorial design," Journal of Water Resource and Protection, vol. 5, no. 9, pp. 867-875, 2013.

[17] B. Wided, M. Khawla, B. K. Eya, and H. Bechir, "Boron removal by electrocoagulation using full factorial design," International Journal of Engineering Research and Technology, vol. 3, pp. 29232928, 2014.

[18] I. Chakchouk, N. Elloumi, C. Belaid, S. Mseddi, L. Chaari, and M. Kallel, "A combined electrocoagulation-electrooxidation treatment for dairy wastewater," Brazilian Journal of Chemical Engineering, vol. 34, no. 1, pp. 109-117, 2017.

[19] E. H. Ezechi, M. Hasnain Isa, S. R. B. M. Kutty, and Z. Ahmed, "Electrochemical removal of boron from produced water and recovery," Journal of Environmental Chemical Engineering (JECE), vol. 3, no. 3, pp. 1962-1973, 2015. 

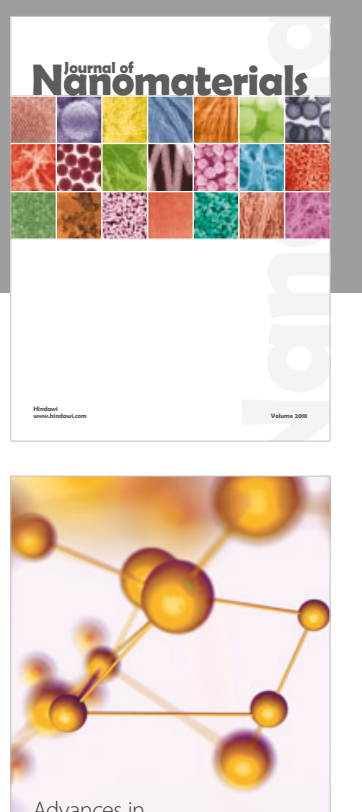

Physical Chemistry
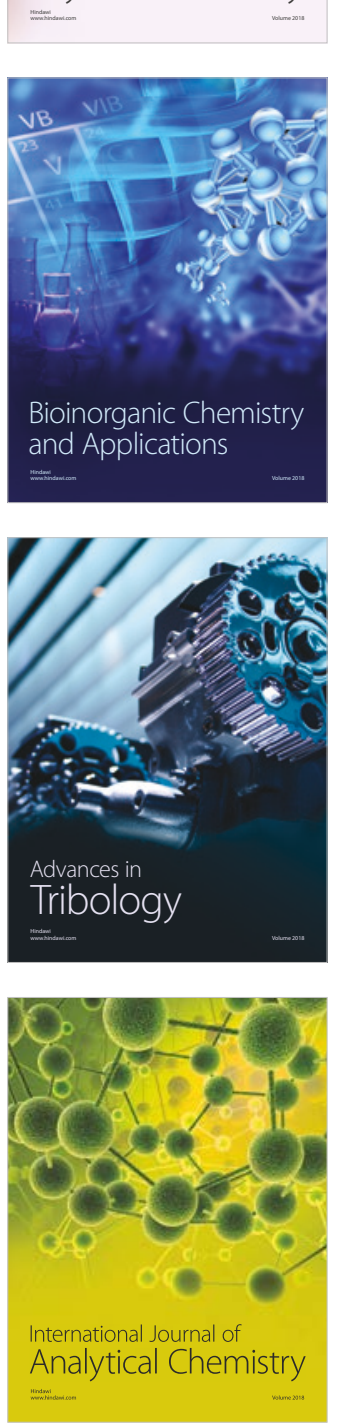

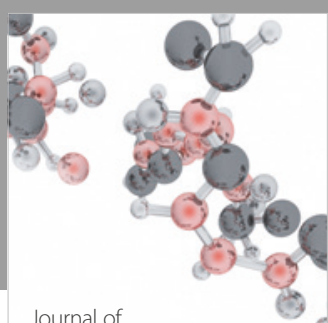

Analytical Methods

in Chemistry

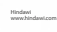

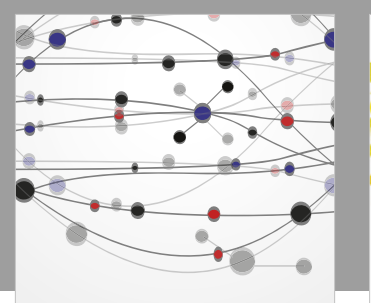

The Scientific World Journal

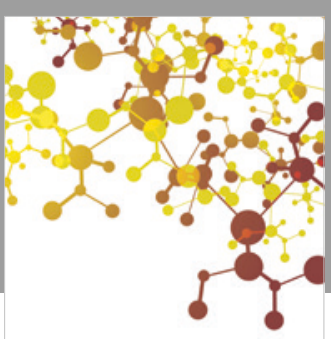

Journal of

Applied Chemistry
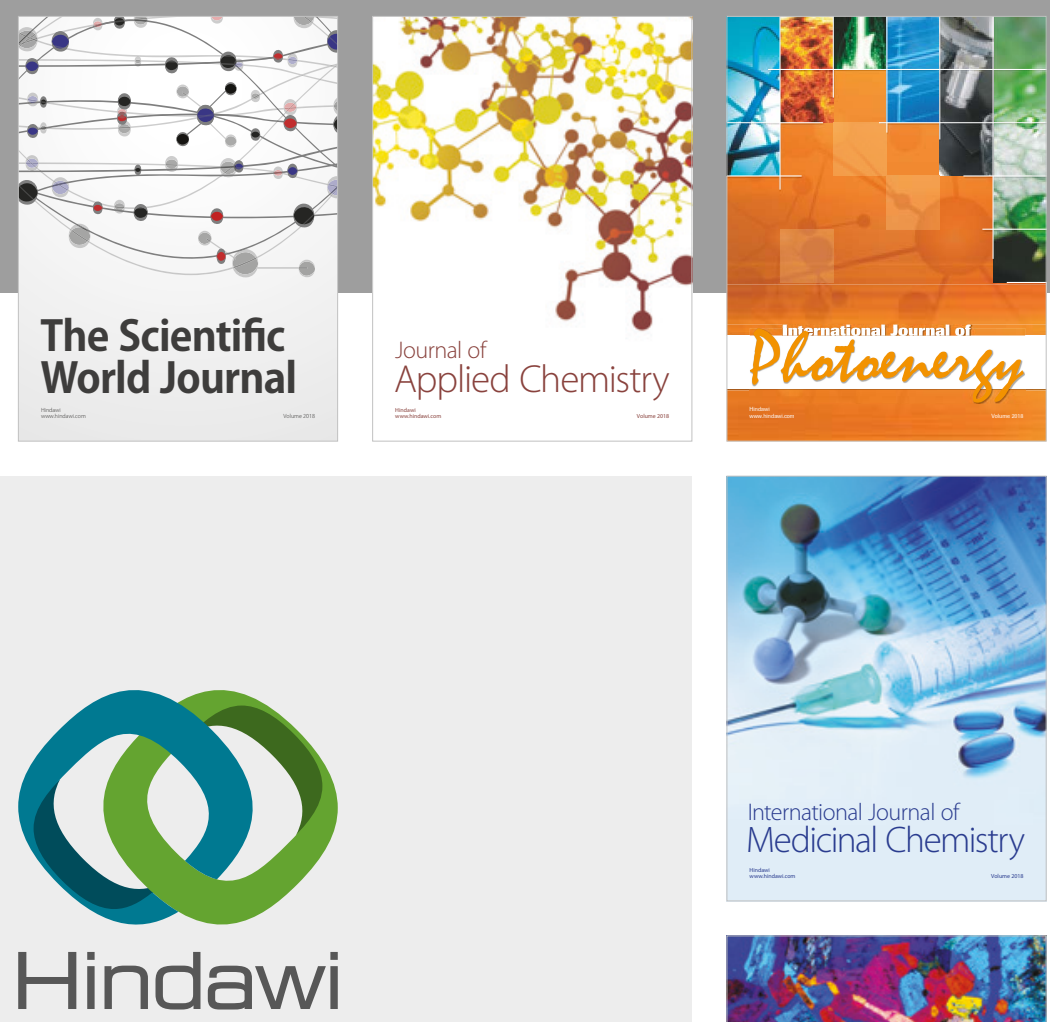

Submit your manuscripts at

www.hindawi.com
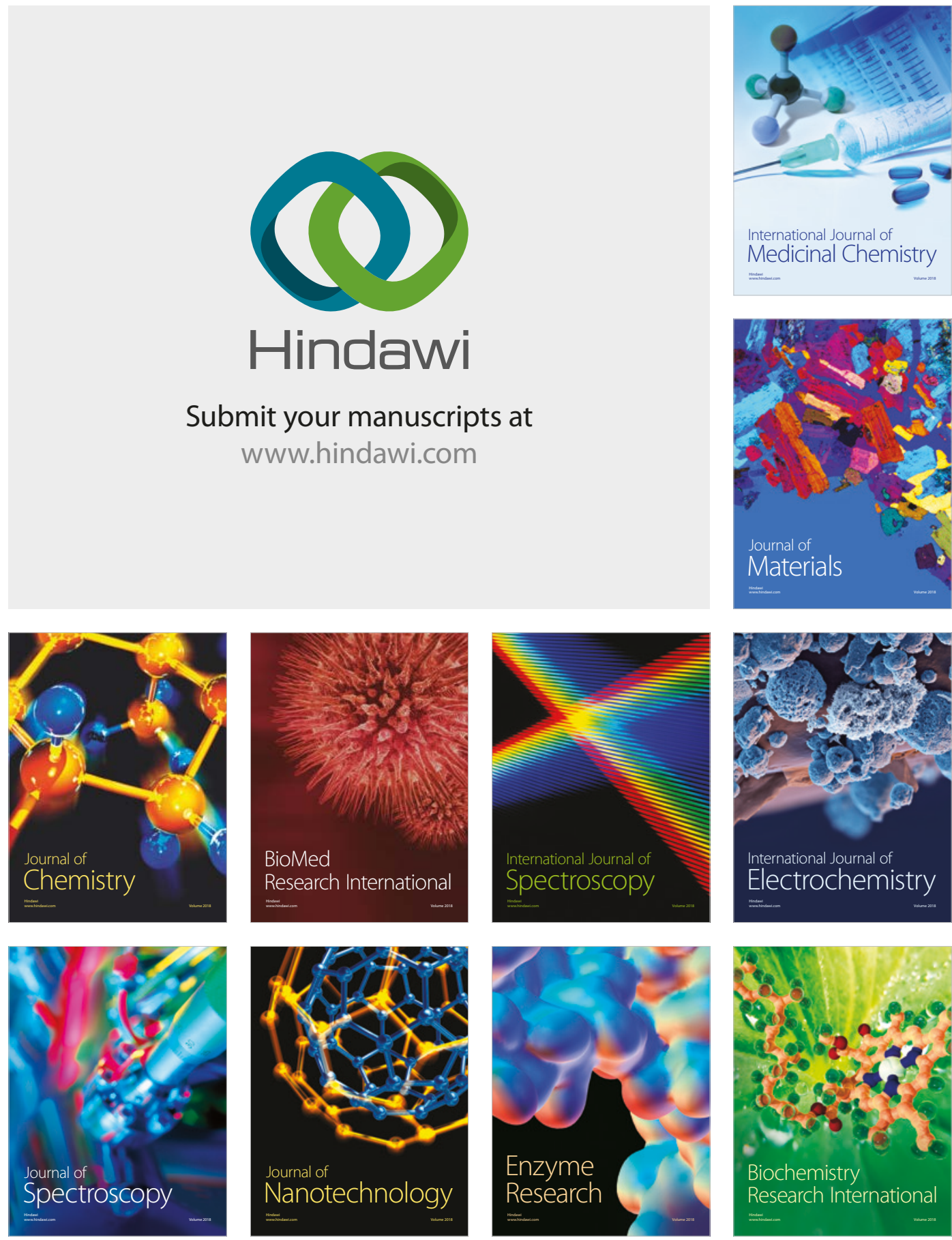
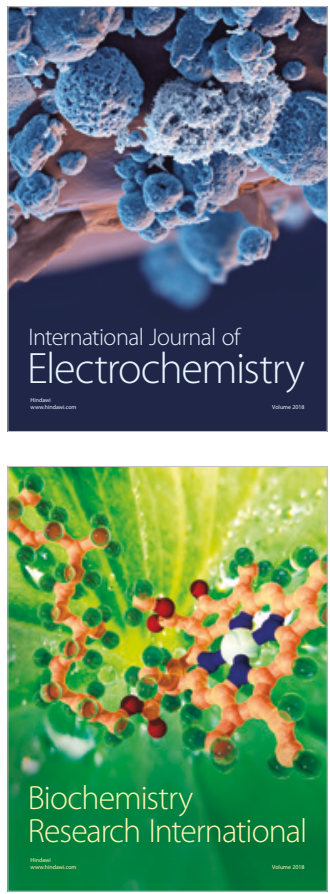